\title{
Judiciário e moralização da política: três reflexões sobre as tendências recentes no Brasil
}

\section{Judiciary and moralization of politics: three reflections on recent trends in Brazil}

Andrei Koerner

\section{Resumo}

O artigo apresenta três ensaios de análise sobre as tendências recentes de reforma do Judiciário, o protagonismo de órgãos, entidades e movimentos de juristas em prol da moralidade pública, e a dinâmica governo/oposição no Brasil após 2003. Foram apontadas as inovações que apresentam a mobilização e o uso dos poderes dos tribunais para o combate à corrupção; as tensões e os conflitos resultantes do estreitamento das oportunidades de discussão no âmbito processual, nas relações entre o órgão de controle, as cúpulas dos tribunais e os juízes; e, enfim, as relações entre o STF e os agentes político-partidários. Os ensaios objetivam estimular uma reflexão mais realista sobre temas de moralidade pública que têm o poder de suscitar um consenso irrefletido e o apelo à ação imediata, mas produzem efeitos profundos e irreversíveis para os que são atingidos por denúncias.

Palavras-chave: Supremo Tribunal Federal. Conselho Nacional de Justiça. Reforma do Judiciário. Combate à corrupção.

\section{Abstract}

The article presents three essays of analysis on recent trends of judicial reform, the role of agencies, organizations and movements of jurists in favor of public morality and dynamic government and opposition in Brazil after 2003. It focuses

* Professor do Depto. de Ciência Política do IFCH/Unicamp, coordenador do Grupo de Pesquisas em Direito e Política do Ceipoc/IFCH/Unicamp, pesquisador do Cedec e do INCT/Ineu. São Paulo - SP - Brasil. E-mail: andreik@uol.com.br. 
on the reform of the judiciary, the role of the CNJ and the Supreme Court in the case of Clean Record Law and Criminal Case No. 470 . They point to the innovations that have the mobilization and use of the powers of the courts to combat corruption, but also the tensions and conflicts resulting from narrowing of opportunities for discussion within procedural relations between the control agency, the domes of the courts and judges and, finally, the relationship between the Supreme Court and political party agents. The test aims to stimulate more realistic reflection on issues of public morality that has the power to elicit consensus thoughtless and immediate call to action, but it produces profound and irreversible for those who are hit by complaints .

Keywords: Supreme Court. National Judicial Council. Judicial Reform. Combating corruption.

\section{Introdução}

O presente artigo $^{1}$ analisa as tensões - emergentes após 2003, em um contexto de reformas judiciais e de mobilização do Judiciário para a promoção da moralidade na política- nas relações entre as instituições judiciais e governamentais. As três reflexões que seguem abordam: as relações entre eficiência e legitimidade substantiva no processo judicial; os limites do órgão de controle interno, que se torna eixo para mobilizações cívicas; e as tensões políticas da atuação recente do Supremo Tribunal Federal (STF) em temas de moralidade pública². As reflexões têm caráter de ensaios interpretativos e apresentam grande

1 Este trabalho tem como base a comunicação apresentada na mesa-redonda "Sistemas de Justiça na América do Sul e as transformações nas instituições democráticas", realizada em 14/08/2013 no PPG em Direito Constitucional da Unifor.

2 O texto retoma em parte e desenvolve análises formuladas em trabalhos anteriores, que serão citadas ao longo do artigo. Koerner, Inatomi e Baratto (2010). Judiciário, Reformas e Cidadania no Brasil. Estado, Instituições e Democracia: República. A d. S. Cunha, B. A. d. Medeiros; e L. M. C. d. Aquino. Brasília, IPEA, Livro 9, vol. 1: 131-74. Koerner, A. (2012). O Judiciário nos dez anos do PT. Os 10 Anos do Governo do PT: Por um balanço crítico. W. L. Rego. IFCH- Unicamp, (inédito); Koerner, A. (2013). "Ativismo Judicial? Jurisprudência Constitucional e Política no STF pós-88." Novos Estudos Cebrap 96 (julho): 69-85; Koerner, A. and L. B. d. Freitas (2013). "O Supremo na Constituinte e a Constituinte no Supremo." Lua Nova 88: p.141-85. 
variedade de evidências empíricas, portanto, servem para estimular a formulação de problemas e hipóteses de pesquisa.

Como pano de fundo, tem-se o investimento das forças políticas no Judiciário para a democratização do país e o quadro criado pela ordem constitucional pós-1988. Desde a Revolução de 1930, foram atribuídos ao Judiciário os papéis de manter o equilíbrio das relações entre os entes constitucionais, e organizar e assegurar as condições para a democracia política, por meio da organização do processo eleitoral e do controle do uso faccioso das instituições governamentais contra o protesto social e a oposição política.

Com a Constituição de 1988, o Judiciário recebeu novos papéis, postos por uma concepção substantiva e promocional de Estado de Direito e de democracia. No entanto, a transição combinou mudanças e continuidades, dentre as quais, a autonomia política, administrativa e financeira dos demais tribunais, e a ampliação das atribuições do STF e dos efeitos gerais e imediatos de suas decisões, sem que se alterassem sua forma de organização e suas relações com os outros poderes do Estado no que tange ao insulamento institucional do Judiciário e à forma de organização do STF.

O crescente protagonismo do Judiciário em questões relativas à moralidade política nos últimos anos pode ser explicado por fatores externos e internos. Entre os fatores externos, destacam-se as mudanças legislativas (especialmente as reformas do Judiciário e a legislação sobre crime organizado e lavagem de dinheiro), as relações entre governo e oposição e destes com as elites judiciais, e o movimento associativo dos juristas. Os fatores internos referem-se às relações entre as direções dos tribunais e o órgão de controle, assim como às relações entre os juízes e as direções dos tribunais ${ }^{3}$.

As vertentes do neoconstitucionalismo e o ativismo, com seus novos procedimentos e técnicas de análise e interpretação da legislação, que ampliam as possibilidades de atuação dos juízes, serão abordadas do ponto de vista de suas implicações para os objetivos políticos dos protagonistas. 
Desde 1988, vê-se uma tendência geral de fortalecimento do papel da justiça pública na regulação das relações sociais. Essa tendência é consistente com políticas em outros setores da administração pública, nos quais houve crescimento e melhora das carreiras de funcionários e de suas condições de trabalho, e investimento na qualidade dos serviços públicos. As reformas judiciais dos anos 2000 ampliaram as possibilidades de ação dos tribunais, mas também as tensões políticas internas e a polarização externa.

As tendências de fortalecimento das instituições judiciais foram acentuadas após 2003 (KOERNER, 2013). Por um lado, havia a convergência normativa do programa do governo Lula, com a ação de juristas progressistas a fim de ampliar o alcance e a efetividade dos direitos fundamentais e programas da Constituição. Por outro lado, havia incentivos para que o governo federal investisse nas instituições judiciais, convergindo taticamente com os propósitos das elites judiciais e o associativismo dos juristas.

Isso porque as eleições presidenciais de 2002 resultaram em um realinhamento partidário. O novo governo estava em oposição ao regime governamental existente e a proposta era modificá-lo. Havia um apoio frágil no Congresso, a presença de elites comprometidas com a coalização derrotada no aparelho de Estado e riscos de invasão das prerrogativas pelos opositores. Dada a sua baixa capacidade de modificar, pela via congressual, a estrutura jurídica do regime governamental existente, o novo governo investiu em outras frentes.

Para as elites judiciais e o associativismo dos juristas, essa situação representava uma oportunidade política para promoverem pautas de fortalecimento das instituições judiciais, contornando-se as divergências e tensões que bloqueavam a reforma judiciária desde o início dos anos 1990.

Para contornar suas dificuldades e reforçar os apoios, o governo Lula incentivou mudanças pela via judicial. Com o apoio de juristas e do associativismo progressista, buscou aproximar-se das elites 
judiciais e promoveu a formação de consensos, simbolizados pelos dois pactos republicanos para a reforma do Judiciário. As ações nesse campo continuaram nos anos seguintes, com mudanças na gestão e procedimentos judiciais, promoção de estudos e iniciativas de reformas legislativas pelo Ministério da Justiça, apoio do governo a entidades e movimentos, e a promoção de direitos.

Porém, a aliança tinha muitos aspectos táticos, uma vez que governo e elites jurídicas não compartilhavam alianças políticas e posições sobre questões substantivas. Os temas centrais do neoconstitucionalismo, adotados pelos juristas progressistas, poderiam ser apropriados e reorientados. Os tribunais poderiam promover a própria agenda, os objetivos, a lógica de atuação e inovar sua orientação jurisprudencial a investir em outros domínios.

O ponto de maior tensão passou a ser o da moralidade política. As iniciativas de combate à corrupção receberam amplo apoio de juristas e magistrados como parte de uma mobilização genérica para a moralização da política e da administração pública, mas suscitaram apoios menos entusiásticos e maiores resistências quando as iniciativas passaram a visar o próprio Poder Judiciário.

As campanhas pela moralidade e eficiência do Judiciário afetaram as acomodações existentes, alteraram coalizões políticas, coibiram práticas arraigadas e desvios tolerados pelos controles internos. Provocaram, pois, novas tensões e conflitos das elites judiciais regionais com as lideranças governamentais e a direção do Judiciário nacional.

As denúncias de corrupção envolvendo o governo federal em 2005 significaram a inversão de papéis nesse campo, dado que a oposição política tomou a iniciativa, apoiada por movimentos cívicos, juristas e elites judiciais. Desse modo, os tribunais mostraram-se mais receptivos a demandas sobre a questão e à polarização produzida no campo político.

A mobilização pela moralidade política acentua as tensões na estrutura institucional conformada pela ordem constitucional pós-1988, pois ocorrem mudanças nas relações internas do Poder Judiciários e nas outras instituições governamentais. Vêm a primeiro plano as tensões 
presentes na Constituição de 1988, tematizadas apenas parcialmente no debate constituinte e nas reformas posteriores, como o insulamento institucional com a precariedade dos instrumentos de controle externo, o modelo de carreira e a hierarquia interna, assim como a legitimidade de um tribunal formado por juízes vitalícios que acumula atribuições constitucionais de Corte Constitucional, Tribunal de Cassação, Alta Corte de Justiça e órgão de cúpula do Poder Judiciário (KOERNER; FREITAS, 2013).

Outro tema a ser considerado é o das contradições de uma prática judicial e do pensamento constitucional que, ao se distanciar da jurisprudência liberal-conservadora capaz de acomodar tanto ao regime autoritário quanto ao neoliberalismo, baseia-se em modelos abstratos de Estado Democrático de Direito para atuar incisivamente sobre a política, sem considerar as condições e os impactos políticos do novo padrão de atuação, com o qual se torna parte de um processo de mobilização política polarizada.

\section{As reformas do Judiciário de 2005 a $2010^{4}$}

Os debates sobre a reforma judiciária no início dos anos 1990 recolocaram alguns dos temas dos períodos anteriores à Constituição de 1988. Tal como os revolucionários de 1930, os movimentos reformistas consideravam que seriam necessárias mudanças profundas não só no Poder Judiciário e nas suas relações com os outros poderes e o acesso à Justiça, mas também maior abertura à participação política e às demandas dos cidadãos. Assim, um Judiciário eficiente e capaz de promover a efetividade dos direitos não seria tanto um conjunto de organizações com métodos racionalizados de gestão dos processos, mas um poder cuja atuação fosse coordenada com os outros poderes para a produção normativa de um Estado Democrático de Direito.

Porém, essas mudanças não aconteceram. Pelo contrário, mantiveram-se restrições - legais ou construídas pela doutrina e

\footnotetext{
4 Cfe. Koerner, Inatomi e Baratto (2010).
} 
jurisprudência - que limitavam o acesso ao Judiciário e o alcance dos processos constitucionais de garantia de direitos. Manteve-se o insulamento institucional, o qual é mais acentuado do que em outros países e abrange as diversas dimensões do Poder Judiciário: a organização dos tribunais, a atuação nos processos, o governo dos juízes e a administração do Judiciário. Ou seja, de modo geral, permaneceu o padrão jurídico das relações com a administração pública e os atores sociais.

Assim, permaneceram as causas que provocavam as deficiências no andamento de processos judiciais envolvendo entes de direito público e sua baixa permeabilidade às dimensões estrutural, social e de diversidade normativa dos conflitos. Elas seriam, em parte, contornadas pela ampliação organizacional da Justiça Federal, não fosse a concomitante expansão dos litígios envolvendo as políticas econômicas governamentais ${ }^{5}$.

O padrão de relações do Judiciário com a administração pública seria tensionado também porque, no contexto da reforma do Estado, a administração pública passou a orientar-se no sentido de buscar o equilíbrio financeiro, limitando-se às receitas orçamentárias e cortando gastos com funcionários públicos, investimentos, manutenção de equipamentos públicos e direitos dos cidadãos. Agências públicas, como a previdência social, procuravam restringir os benefícios aos cidadãos, adotando tanto quanto possível interpretações restritivas dos seus direitos. Nos processos judiciais, atuavam com lógica empresarial, valendo-se sistematicamente de suas prerrogativas processuais enquanto entes de direito público, explorando as lacunas das regras processuais, a ineficiência do Poder Judiciário e as vantagens decorrentes da sua condição de grandes organizações, tal como o fazem as concessionárias privatizadas de serviços públicos e companhias de vários setores da economia, em particular, os bancos. Em um contexto de reestruturação produtiva na indústria e nos serviços, isso resultou em uma verdadeira

5 Como medidas de combate à inflação, reformas administrativa e da previdência, privatizações, desregulamentação da economia e mudanças tributárias. 
"explosão da litigiosidade" nas áreas trabalhista, previdenciária e de relações de consumo.

A Emenda Constitucional $\mathrm{n}^{\circ} 45$ adotou algumas mudanças importantes e positivas, como a criação do direito à razoável duração do processo, a extensão da competência da Justiça do Trabalho, os controles sobre os tribunais de justiça estaduais, os princípios para a expansão da oferta de serviços judiciários, a publicidade e a fundamentação dos atos administrativos dos tribunais. Outras mudanças foram positivas, mas parciais, como a criação do Conselho Nacional de Justiça (CNJ) e a eleição de metade dos membros dos órgãos especiais pelos seus pares. Outras são problemáticas e insuficientes, como a Súmula de Efeito Vinculante, por enfrentarem de forma limitada e com riscos políticos relevantes (dadas a posição e a forma de organização do STF ${ }^{6}$ ) a problemática da coordenação das decisões judiciais com a produção normativa e seu efeito vinculante mais imediato para a administração pública e os jurisdicionados. Essas limitações se mostram no fato de que permanecem sem solução grandes "gargalos" do processamento dos litígios, como os precatórios e os executivos fiscais, e inovações a fim de tornar a justiça mais ágil tiveram efeitos problemáticos para o reconhecimento e a efetividade dos direitos sociais, como é o caso dos juizados especiais previdenciários.

Foi realizada a análise da reforma judicial brasileira entre 2005 e 2010, na qual foi levantado um total de 222 medidas, classificadas segundo seus domínios, meios e objetivos. Por "domínios", entendese a área do Direito (Civil, Penal, Processual Civil, Processual Penal, Processual em Geral e Administrativo). Por "meios", consideram-se a oralidade, a desformalização, a simplificação, a informatização, a

6 A posição do STF, que combina o papel de órgão de cúpula do Judiciário e a concentração de poderes de controle da constitucionalidade com os de revisão de todos os tipos de processos que transitam na Justiça do país pode levar tal órgão a utilizar a Súmula de Efeito Vinculante, para disciplinar os órgãos inferiores do Poder Judiciário ou da administração, ou para efetivar políticas públicas específicas. A coordenação com o governo é facilitada pela concentração dos poderes e a permanência dos ministros do STF por longo tempo em seus cargos, pois isso os torna menos permeáveis às tendências nos partidos políticos, na comunidade jurídica e na opinião pública. 
conciliação, a supressão de recursos, a uniformização da jurisprudência, a especialização de processos e organizações judiciais, a melhoria da infraestrutura, as normas para a carreira de magistrado, o consenso de cúpulas sobre a política judiciária etc. Em "objetivos", encontramse a produção de normas procedimentais para a coordenação de decisões (diretrizes para a ação conjunta com outros poderes do Estado e a sociedade, prevenção de litígios e generalização dos efeitos das decisões), a ampliação do acesso ao Judiciário, o reconhecimento de direitos (setores subalternos e discriminados), a racionalização do Judiciário (eficiência e modernização da gestão), a efetividade das decisões $^{7}$, a responsividade dos juízes (o controle externo e as garantias de carreira), o fortalecimento da cidadania e a formação de cidadãos etc $^{8}$. A classificação não tem caráter exaustivo, pois as reformas compreendem várias medidas e estas podem entrar em mais de uma classe.

A maioria dos meios utilizados acaba servindo para alcançar o objetivo de racionalização ou eficiência do Poder Judiciário. Os objetivos de produção de normas para coordenação de decisões, prevenção de litígios, ampliação do acesso, reconhecimento de direitos e fortalecimento da cidadania estão em apenas alguns recursos e não se encontram, em geral, nos projetos de leis, mas nas recomendações e orientações de caráter não obrigatório, e nas iniciativas particulares de juízes e tribunais. Nota-se que, para a ampliação do acesso à Justiça, é negligenciada a especialização ${ }^{9}$, utilizando-se, sobretudo, os meios informais de atuação, como a conciliação, a simplificação e a oralidade.

Desde 2008, a Secretaria de Reforma do Judiciário (SRJ) passou a cuidar não somente de propostas legislativas, mas também da execução de programas de ampliação do acesso à Justiça. Articulada com o Programa Nacional de Segurança com Cidadania (PRONASCI),

\footnotetext{
Efetividade das decisões, aqui, tem o sentido de garantir a execução de sentenças finais. Como o objetivo de fortalecer a área de comunicação e propaganda do Judiciário.

Sobre a especialização dos tribunais como parte das políticas de ampliação do acesso à Justiça, ver Cappelletti e Garth (1988).
} 
a SRJ passou a visar ações voltadas para o fortalecimento do Estado Democrático de Direito, entendido em quatro tipos principais de ações: o combate à violência contra mulheres, para efetivar a Lei Maria da Penha (Lei n. 11.340); a construção de meios alternativos de resolução de conflitos, como o projeto "Justiça Comunitária", do Distrito Federal; a assistência jurídica a presos e familiares; e a capacitação dos profissionais do sistema de Justiça para lidar com temas de Direitos Humanos e mediação pacífica de conflitos.

Essas ações da SRJ foram complementadas pela assinatura, em 13 de abril de 2009, do segundo pacto entre os três Poderes estatais, o "II Pacto Republicano de Estado por um sistema de Justiça mais acessível, ágil e efetivo". Seu intuito é incentivar a produção de projetos de lei e a expansão de iniciativas privadas de juízes e tribunais. Para isso, tanto a SRJ quanto o CNJ e outros órgãos passam a colaborar diretamente. Os objetivos do segundo pacto não se diferem do primeiro, versando especialmente sobre o acesso à Justiça, a busca pela eficiência do Poder Judiciário e a maior efetividade do sistema penal no combate à violência e à criminalidade.

O padrão de reformas é apenas reativo às mudanças na demanda e na estrutura do Estado, pois busca aumentar o controle externo sobre os juízes, a eficiência do Poder Judiciário e não coloca em questão o modelo das relações entre os poderes que se constituíram no Estado brasileiro contemporâneo. Não são tematizados os problemas da coordenação dos poderes, a baixa permeabilidade das agências administrativas do Estado às demandas e necessidades dos cidadãos e as questões postas pela temática do acesso à Justiça - a qualidade da prestação jurisdicional, a variedade de modelos de prevenção e resolução de conflitos e a efetividade dos direitos de cidadania. Nem leva em consideração as relações hierárquicas internas ao Poder Judiciário e seus efeitos para o padrão da prestação jurisdicional que é realizado.

Dado o perfil das medidas adotadas e os objetivos fixados para a continuidade da reforma, colocam-se questões sobre o seu alcance e efeitos, e o perfil das reformas futuras. Como as reformas futuras 
conjugarão medidas para aumentar a eficiência do Judiciário com a efetividade dos direitos e garantias constitucionais? As medidas simplificadoras do processo judicial adotadas até o momento continuarão a ser centrais em reformas que visam ampliar o acesso ao Judiciário e promover os direitos humanos? Será necessário redefinir a eficiência do Judiciário, considerando-se outros objetivos além da modernização e racionalização da gestão? É desejável que as propostas que extrapolam a racionalização e a modernização da gestão continuem a depender de medidas informais resultantes de iniciativas particulares de juízes e tribunais ou elas devem ganhar corpo legal e levar a mudanças efetivas também nas instituições estatais e nas condições mais amplas para o exercício dos direitos?

\section{O CNJ: órgão de controle ou liderança em campanhas cívicas}

O Conselho Nacional de Justiça (CNJ) foi criado pela Emenda Constitucional $n^{\circ} 45$ para controlar a atuação administrativa e financeira do Poder Judiciário e o cumprimento dos deveres funcionais dos juízes. É um órgão da cúpula federal, composto por: juízes de todas as instâncias, indicados pelos tribunais superiores; membros de profissões jurídicas (advocacia e promotoria), indicados pelas respectivas cúpulas federais; e dois cidadãos indicados pelas Casas do Congresso.

O CNJ buscou dar alcance geral à sua ação corretiva, adotando resoluções sobre a administração dos tribunais e intensificando a coleta de informações, a partir das quais foram fixadas metas de produtividade para os juízes. Ao ser empossado na presidência do Conselho, em março de 2008, o ministro Gilmar Mendes apontou a necessidade de se construir consensos com os dirigentes do Judiciário. Então, o CNJ passou a provocar mudanças na gestão do Judiciário, promovendo planejamento estratégico e medidas para melhorar a eficiência dos serviços. A reforma regimental de 2008-2009 proporcionou instrumentos para tal propósito. 
Uma questão geradora de tensões internas foi o controle dos tribunais devido ao aumento da sua eficiência. Como parte da construção de consensos, o CNJ promoveu o Encontro Nacional do Judiciário, realizado em Brasília, em 2008, que tratou da modernização do Judiciário, do aperfeiçoamento da gestão dos tribunais e da melhoria da prestação jurisdicional, a fim de unificar as "diretrizes estratégicas de atuação, com base na cooperação mútua entre as instituições". Do encontro, resultou a Carta do Judiciário, firmada pelos presidentes de tribunais, os quais se comprometeram "com o planejamento e com a execução, de forma integrada, de um conjunto de ações voltado ao aperfeiçoamento da instituição e à efetividade da prestação jurisdicional". Suas diretrizes seriam, entre outras: a celeridade, a facilitação e a simplificação da prestação jurisdicional e do acesso à Justiça; e a ampliação dos meios de alcance à informação processual. Seriam realizadas reuniões preparatórias regionais, cujos resultados seriam debatidos e validados em um novo encontro para consolidar e elaborar o planejamento estratégico do Poder Judiciário.

No $2^{\circ}$ Encontro Nacional do Judiciário, realizado em Belo Horizonte, em 2009, o compromisso se traduziu em 10 metas a serem atingidas até o final do ano. A meta 2 era: "[i]dentificar os processos judiciais mais antigos e adotar medidas concretas para o julgamento de todos os distribuídos até 31.12.2005 (em $1^{\circ}, 2^{\circ}$ grau ou tribunais superiores)". O objetivo era assegurar o direito constitucional à "razoável duração do processo judicial”, o fortalecimento da democracia, além da eliminação dos estoques de processos responsáveis pelas altas taxas de de congestionamento ${ }^{10}$. Mas a Resolução $n^{\circ} 70$, de março de 2009, determinou o cumprimento das metas até o final do ano, de modo que objetivos consensuais de um plano estratégico se tornaram regras obrigatórias para os tribunais. O $2^{\circ}$ Pacto Republicano para tornar mais

\footnotetext{
10 As demais metas tratam de eficiência operacional, acesso à Justiça, responsabilidade social, alinhamento e integração, atuação institucional, gestão de pessoas e infraestrutura. Ver em $<$ http://www.cnj.jus.br/images/stories/docs_cnj/resolucao/rescnj_70_ii.pdf >. Acesso em: 18 fev. 2010.
} 
acessível e ágil o sistema de Justiça deu nova legitimidade à iniciativa. Os tribunais determinaram o estrito cumprimento da resolução, o que levantou debates e críticas às medidas quanto à sua constitucionalidade, adequação e consequências para a qualidade da jurisdição. Isso porque as medidas para aumentar a eficiência envolvem necessariamente a consideração da efetividade dos direitos e esta remete às condições mais gerais de exercício dos direitos.

O que a iniciativa de 2009 evidencia é que o Conselho Nacional de Justiça tem instrumentos limitados para controlar a atuação dos tribunais. Além de revelar os limites do poder normativo e do planejamento estratégico do CNJ, desgastou sua capacidade de construir consensos com as cúpulas do Judiciário e perdeu legitimidade junto aos juízes de primeira instância. Assim, desde então, o Conselho encontrou resistências dos tribunais a suas iniciativas nesse campo, resultando em metas menos ambiciosas e que que não foram atingidas em grande parte dos tribunais.

Como se viu com a análise da meta 2, a iniciativa do CNJ de promover mudanças administrativas profundas no Judiciário levanta o problema da sua capacidade de levar a cabo essas reformas, pois dependem, ao menos, do apoio das cúpulas dirigentes estaduais. Por sua vez, políticas que promovam controles mais estritos sobre os desvios na administração do Judiciário e sobre o desempenho dos juízes alteram as relações destes com a cúpula e levam à questão da legitimidade dos órgãos dirigentes do Poder Judiciário. Isso, por sua vez, levanta os temas da democracia interna do Judiciário - a participação dos juízes na formação dos órgãos dirigentes e nas decisões sobre o planejamento e recursos - e da democratização "externa" - a participação de representantes de outros poderes políticos e da sociedade nas decisões sobre política judiciária.

Em análise sobre a atuação do Conselho Nacional de Justiça, Roberto Fragale (no prelo) apresenta as limitações desse novo órgão quanto ao controle e à formulação de políticas para o Poder Judiciário. Fragale pesquisa as lógicas de ação que implicam a captura e neutralização do CNJ pela cúpula dos poderes em Brasília, que já 
representava uma reduzida abertura à participação e ao controle externo. Apenas os representantes da Justiça Federal tinham vínculos com as redes associativas, enquanto os representantes da sociedade civil teriam proximidade com os partidos, a Justiça Estadual, a própria cúpula do Judiciário nacional, o STF e o CNJ. A construção da agenda é gerada endogenamente por este, sendo seu processo decisório prisioneiro da representação corporativa e centralizada da composição do conselho. Isso indica uma oscilação entre dois papéis: o de formulador de policy e o de controle, ou a sobreposição da esfera administrativa e judicial.

O modelo institucional do Conselho Nacional de Justiça admitiria, teoricamente, que a pauta e as decisões do órgão fossem abertos à participação de agentes externos. No entanto, a tendência predominante parece ser a de que o $\mathrm{CNJ}$ se tornou um órgão subordinado à cúpula do Judiciário Federal, o STF, e que não exerce o controle externo sobre a magistratura, mantendo intactas e reforçando as estruturas de poder autônomas que se exercem no interior de cada tribunal. Fragale (no prelo) critica as decisões do CNJ a respeito da carreira, deveres funcionais e processos de trabalho dos juízes, que revelam uma concepção burocrática, individual e isolada da decisão judicial. Elas tendem a encapsular o magistrado, criando obstáculos à participação mais ativa em espaços associativos profissionais e da sociedade em geral.

As tensões entre o Conselho Nacional de Justiça e os dirigentes dos tribunais se tornaram agudas diante do controle do nepotismo e da corrupção no Judiciário. A atuação inicial do CNJ se voltou, sobretudo, ao recebimento de reclamações sobre juízes e tribunais, à verificação da conformidade dos atos administrativos dos tribunais com os princípios da administração pública e ao controle disciplinar sobre juízes. Além disso, promoveu a informatização dos tribunais, o aprimoramento de estatísticas e relatórios, e semanas de conciliação para agilizar processos. Sua primeira queda de braço com os tribunais foi determinar a aplicação imediata da regra da eleição para os órgãos dirigentes. Em seguida, coibiu o nepotismo e o desperdício de recursos públicos. 
A corregedoria recebeu reclamações de desvios funcionais, abuso de poder e excesso de prazo de processos; ademais, reexaminou processos disciplinares e fixou regras padronizadas para funcionários. Procurou aproximar-se das suas homólogas nos tribunais, visando uma atuação integrada e efetiva, buscando resultados concretos para o cotidiano do Judiciário, tomando medidas disciplinares e combatendo a morosidade e a impunidade. Desde 2007, a corregedoria teve uma atuação mais ativa, promovendo inspeções nos estados e audiências públicas para receber reclamações dos cidadãos contra os serviços judiciários.

O combate à corrupção tornou-se o tema central da gestão da ministra Eliana Calmon como corregedora, confrontando-se com o presidente do CNJ, o ministro César Pelluso, a respeito dos poderes do órgão. Ela saiu fortalecida e afirmou um perfil protagonista para os juízes. Esse protagonismo tem sido promovido em campanhas institucionais do Poder Judiciário, em mobilizações cívicas de suas associações de classe (voto consciente) e na formação das Escolas de Magistratura.

O combate à corrupção, para a corregedora do Conselho Nacional de Justiça, ia além do controle interno, pois visava todo o aparelho do Estado. Ela defendia a união dos órgãos de controle, apostava no caráter promocional e pedagógico da campanha, e na participação da sociedade brasileira, pois o exercício da cidadania não deveria se limitar ao voto nas eleições ${ }^{11}$. O CNJ, então, passou a promover campanhas envolvendo a efetividade dos direitos de cidadania e a atuação dos órgãos judiciais nos setores da administração pública que são controlados pelo Judiciário e em outros campos ${ }^{12}$.

11 Palestra em 23/08/2012, no VIII Encontro Nacional de Controle Interno, promovido pelo Conselho Nacional dos Órgãos de Controle Interno (CONACI), em São Paulo, disponível no site do CNJ (www.cnj.jus.br).

12 Em 2012, o CNJ promovia as seguintes campanhas: Campanha Maria da Penha, para a divulgação da lei e o monitoramento da sua aplicação; Saúde e Meio Ambiente, para a prevenção de conflitos judiciais na área da saúde, envolvendo campanhas antidrogas e a adoção de políticas públicas em prol da melhoria da prestação jurisdicional nas atividades de gestão socioambiental; Sistema Carcerário e Execução Penal, com ações para reinserir presos e egressos do sistema 
Essa atuação cívica tem sido justificada por vários integrantes da cúpula do Judiciário como a missão dos tribunais, adequada à sociedade atual, em substituição aos demais poderes, e que deve ser privilegiada em relação às suas funções tradicionais de resolução de conflitos interindividuais. Para a então corregedora Eliana Calmon, o Judiciário deveria utilizar sua força para mudar a realidade brasileira ${ }^{13}$. Em palestra na Escola Paulista de Magistratura, em maio de 2013, o ministro Ricardo Lewandowski afirmou que o protagonismo do Judiciário era o seu papel neste século. Lewandowski partiu da premissa histórica de que o século $X I X$ foi o da proeminência do Legislativo, o século $X X$, do Executivo, portanto, o século XXI seria do Judiciário, cuja tarefa seria controlar os demais poderes e substituir a inação deles pela proteção e promoção dos direitos. Assim, o papel do juiz não seria o de se deter em casos individuais de baixa relevância, mas de incidir na promoção de políticas públicas para a promoção de direitos.

Por sua vez, as associações de magistrados mantêm ativa e crescente a atuação em defesa da melhoria das suas condições de trabalho e de mudanças institucionais no Judiciário junto ao $\mathrm{CNJ}$ e ao Legislativo ${ }^{14}$. Mas elas têm se engajado também a favor da ampliação dos direitos individuais e coletivos. Assim, nos anos 2000, emergiram novos temas e desafios para a atuação dos magistrados no espaço público, permeável às demandas sociais e aberto às diferenças entre os sujeitos.

penitenciário na sociedade civil; Mutirão Carcerário, para conhecer o sistema de justiça criminal, revisar as prisões, promover a reinserção e elaborar proposições de reformas na justiça criminal; Cidadania, Direito de Todos, voltada ao registro civil de nascimento dos povos indígenas; Infância e Juventude, que compreende programas para estimular o reconhecimento de paternidade e promover a regularização do registro civil de jovens e crianças em situação de adoção e os acolhidos em abrigos; Cadastro Nacional de Adoção, para auxiliar juízes das varas da infância e da juventude na condução dos procedimentos de adoção; Cadastro Nacional de Adolescentes em Conflito com a Lei, para reunir dados fornecidos pelas Varas de Infância e Juventude de todo o país sobre os adolescentes nesta situação; Registro Civil, para o registro civil de nascimento e a documentação básica.

13 Palestra na abertura do Seminário Nacional para a Erradicação do Trabalho Infantil, em 22/8/2012, em Brasília. Disponível no site do CNJ (www.cnj.jus.br)

14 Ver Fragale (no prelo) e Caldeira (2010) 
A combinação dessas mudanças tem algo de paradoxal. Por um lado, reformas que procuram racionalizar o funcionamento dos tribunais; por outro, iniciativas que buscam associar o Judiciário, o movimento associativo e os juízes individualmente em iniciativas para a efetivação dos direitos de cidadania. O paradoxo é porque as reformas racionalizadoras tendem a esvaziar as oportunidades de discussão nos espaços em que se exerce a jurisdição, os quais se restringem às oportunidades de controvérsia entre diferentes concepções de justiça e bem público. No entanto, é enfatizado o papel promocional do Judiciário e dos juízes enquanto "elites responsáveis", associadas à mudança social para a promoção de determinados direitos e bens públicos. Em outros termos, é valorizado um perfil de juízes técnicos no enfoque dos casos e na condução de processos, e também como uma espécie de "engenheiros sociais", ativamente engajados na produção de determinados objetivos coletivos. Tem-se, então, um papel que é promocional de bens públicos, mas pode ser redutor dos espaços para a manifestação e o reconhecimento das diferenças no próprio processo judicial.

Esse paradoxo é acentuado por outras características do Judiciário brasileiro: a hierarquia interna e seu insulamento institucional. As reformas judiciárias e a atuação do Conselho Nacional de Justiça tendem a fortalecer o padrão hierárquico nas relações internas a cada tribunal, ao mesmo tempo em que o órgão não é capaz de aumentar a permeabilidade à participação da sociedade, o que seria indispensável para tornar mais efetivos os controles sobre os dirigentes dos tribunais. Daí que a atuação do Conselho no combate à corrupção e à ineficiência incidiu num ponto politicamente sensível, sem ser capaz de limitar a autonomia dos tribunais no campo da política judiciária. Esse ponto já provocara enfrentamentos anteriores, como a CPI do Judiciário, patrocinada pelo senador Antônio Carlos Magalhães. A associação de controle externo com denúncias de corrupção e nepotismo no Judiciário fortaleceu resistências e reações das elites judiciais regionais ao CNJ, às orientações reformistas do governo e à cúpula do Judiciário federal.

Essas tensões dizem respeito às relações do Conselho Nacional de Justiça com as cúpulas dos tribunais e à capacidade dele de gerir 
as relações entre os juízes e a direção dos tribunais. Com os outros poderes e as lideranças políticas, os problemas são a orientação e as consequências do protagonismo do CNJ e dos juízes na promoção dos direitos e da moralidade pública. Quais as repercussões dessas resistências e lutas políticas em torno do combate à corrupção? Quais os seus efeitos para as relações do STF com os outros poderes políticos da República?

\section{O STF e os conflitos entre os poderes políticos}

Nos anos 1990, os debates entre constitucionalistas assumiram a forma de uma oposição geral entre duas correntes: de um lado, os positivistas, que associavam os dissidentes do liberalismo institucional e os juristas que apoiaram o autoritarismo; do outro, os comunitaristas, ou pós-positivistas. Essa oposição doutrinária tendia a ser recoberta pela do apoio ou oposição ao regime liberalizante ${ }^{15}$.

No governo Sarney e nos dois mandatos de Fernando Henrique, mantiveram-se no STF ministros nomeados pelos militares e a maioria dos novos integrantes eram alinhados ao liberalismo institucional. Assim, até o início do governo Lula, apenas três ministros (Sepúlveda Pertence, Maurício Corrêa e Nelson Jobim) haviam participado ativamente da luta pela democratização.

Outras pesquisas notaram a seletividade e heterogeneidade das decisões do Tribunal no período (CARVALHO, 2005; PACHECO, 2006; VIANNA et al., 1999). No quadro político do início dos anos 1990 - de instabilidade política e crise do desenvolvimentismo -, o STF conformou a jurisdição constitucional de modo a limitar a frequência e o alcance de sua atuação em comparação com a programada pela Constituinte. Ministros do antigo regime e os de orientação liberal elaboraram um

15 Os parágrafos que seguem retomam em parte o artigo de Koerner A. (2013, p. 69-85). 
regime jurisprudencial que concorreu para a estabilização democrática e a constituição de um regime liberalizante. Ou seja, o STF combinou efetivação e neutralização de regras constitucionais segundo os domínios e o seu sentido estratégico para a direção política do governo federal, voltado às reformas liberalizantes do Estado.

As reformas depois de 2003 consolidaram o STF como jurisdição constitucional concentrada, permitiram maior controle da agenda e a ampliação dos impactos das decisões. O governo Lula sinalizou a modificação do caráter do STF ao buscar uma composição mais plural e engajada à concretização da Constituição. Aos tradicionais critérios de escolha dos ministros (origem regional, carreira jurídica e apoio de lideranças políticas nacionais relevantes) se somaram atributos pessoais ou histórias de vida (gênero, etnia, atuação ou apoio a movimentos sociais). Alguns nomeados era próximos aos partidos de esquerda e movimentos populares, mas outros eram juízes ou juristas profissionais sem atuação política, ligados a lideranças de partidos de centro ou entidades de representação das profissões jurídicas.

As perspectivas de bloqueio pelo Supremo Tribunal Federal das políticas do novo governo não eram claras, dada a maior fragmentação partidária e o insulamento das profissões jurídicas, tornando menos diretos seus vínculos com partidos e ideologias do que nos Estados Unidos. Além disso, as questões emergentes implicariam que os próprios ministros do Supremo redefinissem suas posições e se manifestassem de novas maneiras. Depois de 2003, houve uma importante renovação do STF, dada a aposentadoria de vários ministros. Assim, os incentivos externos encontraram renovação interna para uma nova orientação jurisprudencial.

Com as reformas processuais e a Emenda Constitucional $\mathrm{n}^{\circ}$ 45, houve importantes mudanças no padrão de litigação no STF, o qual passou a ter uma atuação mais consistente com a afirmação de direitos constitucionais, decidindo uma série de questões política 
e normativamente controversas ${ }^{16}$. Os instrumentos utilizados para controle da constitucionalidade se tornaram mais diversificados, aumentou o número de casos ingressados e julgados e de leis federais invalidadas. A participação nos processos constitucionais foi ampliada e decisões relevantes desbloquearam questões controversas na sociedade. A jurisprudência teve impactos mais concretos, pois o tribunal cuidou de supervisionar a conformidade dos demais entes a ela (POGREBINSCHI, 2011; SUNFELD, 2010; COSTA et al., 2010). Os termos "neoconstitucionalismo" e "ativismo judicial" são utilizados para justificar uma perspectiva principiológica na interpretação e aplicação das normas jurídicas, o protagonismo dos tribunais na efetivação dos direitos em nome da suposta omissão dos outros poderes do Estado, e a orientação concretizante dos direitos nas decisões judiciais.

Esse novo tribunal, constituído por juízes com outra formação e concepção sobre o papel da justiça constitucional e a interpretação da Constituição, atuou de forma convergente com o governo em questões relativas à maior efetividade de direitos e promoção de políticas sociais. A agenda reformista do governo encontrava repercussão na atuação positiva do STF nesses campos. Ao promoverem a efetivação da Constituição, os ministros do STF reforçaram seus apoios políticos e sociais. Assim, conformou-se um novo regime jurisprudencial, articulado com o regime governamental promocional do governo Lula.

As denúncias de compra de votos e de práticas clientelistas envolvendo a base aliada do governo, em 2005, representaram uma oportunidade para a oposição política inverter os papéis no jogo político e promover a moralidade pública, patrocinando o combate à corrupção,

16 Uma lista não exaustiva inclui os casos: Marcha da Maconha; Raposa Serra do Sol; racismo e antissemitismo (STF-HC 82.824, de 2004); constitucionalidade das pesquisas científicas em células embrionárias humanas (STF-ADC 12 DJ 20.08.2008); direito de união homoafetiva; prisão de depositário infiel. Controvérsias políticas são os casos: "Ficha Limpa"; Lei de Anistia; Cesare Battisti; direito de greve no setor público e aposentadoria especial aos servidores públicos (MI 721, MI 670, MI 708 e MI 712); fidelidade partidária (STF-MS 26.602, de 2008); direito de a minoria requerer a instauração de comissões parlamentares de inquéritos (STF- MS 24.831, de 2006); proibição de nepotismo na administração pública (STF-ADC 12, de 2008). 
numa tentativa de tornar o tema uma questão crítica nas eleições de 2006. Porém, apesar dos escândalos, as eleições mostraram o fortalecimento do apoio ao governo e a consolidação de uma aliança que assegura sua maioria parlamentar no plano federal.

As denúncias esfriaram as relações do governo Lula com movimentos sociais e cívicos. Esses movimentos, aos quais se associaram elites judiciais reativas, apoiaram as fortes pressões da oposição política e da mídia sobre o governo. Essa nova aliança passou a investir em espaços institucionais do Judiciário, procurando reforçar o combate à corrupção, a ética na política e eleições limpas. A arena institucional do Judiciário se mostrou receptiva à mobilização da moralidade política à medida que os tribunais se mostraram mais ativos em relação ao tema, que recebia o apoio das entidades e associações de juízes. Se o movimento pela ética na política é mais antigos e amplo que a oposição política ao governo, sua atuação política adquiriu novos significados e implicações. Do mesmo modo, as relações na arena do Judiciário se alteraram e receberam novos sentidos e implicações políticas.

O combate à corrupção tem sido tema central do debate público brasileiro desde a transição (KOERNER, 2012). Ele tem forte conotação positiva, pois se baseia em um consenso genérico e difuso pela moralidade política e produz adesão imediata dos interlocutores, que se veem compelidos a se manifestarem favoravelmente.

Acusações de corrupção, abuso ou desvio de poder são armas políticas de alto calibre, pois produzem efeitos certeiros sobre a reputação e as perspectivas de carreira política, e tendem a limitar o apoio político e as formas e opções de ação dos governos. Mas corrupção é o nome que se dá a práticas muito distintas, com impactos e significados diferentes para a máquina pública. Cabem no nome genérico desde o financiamento ilegal de campanhas até o uso de cargos e recursos públicos para benefício pessoal ou favorecimento de terceiros. Nos últimos anos, foram adotadas inúmeras iniciativas para coibir práticas corruptas, como a lei para o financiamento de campanhas políticas, o controle da lavagem de dinheiro, a controladoria geral e a recente lei de acesso à informação. 
São significativos os julgamentos do STF no caso da "Lei da Ficha Limpa" (IÓRIO FILHO; DUARTE, 2012). A partir de fraudes, violações e corrupção eleitoral no estado do Rio de Janeiro, movimentos da sociedade civil, associações e entidades de profissionais do Direito, com o apoio de integrantes do Judiciário e de outras instituições judiciais, lançaram o Movimento de Combate à Corrupção Eleitoral (MCCE), pela impugnação das candidaturas de indivíduos condenados por crimes graves ${ }^{17}$. Em 2008, a Associação dos Magistrados do Brasil (AMB) propôs a Arguição de Descumprimento de Preceito Fundamental (ADPF) $\mathrm{n}^{\circ} 144$, que demandava a inelegibilidade mesmo sem o trânsito em julgado de ações com decisão condenatória de conteúdo grave ou desabonador (criminais ou de improbidade). A decisão do STF foi desfavorável, por 9 votos a 2 (vencidos: Ayres Britto e Joaquim Barbosa). Em resposta, o MCCE desencadeou um movimento nacional que, sob a bandeira da moralidade pública, iniciou um projeto de lei para criar a restrição desejada, obtendo o apoio de mais de um milhão e seiscentas mil assinaturas em todo o país, sendo incentivado por autoridades judiciais, inclusive do STF.

A mobilização levou à aprovação da Lei da Ficha Limpa, uma típica lei à qual os parlamentares não poderiam se opor sem altos custos eleitorais. O projeto foi apresentado ao Congresso Nacional no final de setembro de 2009, aprovado por unanimidade nas duas Casas e sancionado em 4 de junho de 2010, a apenas quatro meses do primeiro turno eleitoral daquele ano. Assim, tornavam-se inelegíveis candidatos que tivessem recebido decisão judicial condenatória, penal ou eleitoral, proferida por órgãos colegiado, mesmo que não transitada em julgado, isto é, ainda que pendente de decisão de tribunal superior. Dada a data de aprovação da Lei da Ficha Limpa, ela deixava de atender o chamado princípio da anualidade (artigo 16 Constituição Federal), segundo o qual não são aplicáveis as alterações nas regras eleitorais aprovadas a menos um ano da eleição.

17 Sobre o movimento pelo combate à corrupção eleitoral, ver Caldeira (2010) 
A lei foi redigida com delegações amplas para o Judiciário implementá-la. A orientação jurisprudencial existente nesse domínio poderia levar a supor que o Judiciário tenderia a limitar o impacto das novas regras. Desde a Revolução de 1930 até o início dos anos 2000, o STF adotava a postura autorrestritiva de garantir as condições para a competição política e organizar o processo eleitoral, mas, a partir de 2002, o STF e o TSE passaram a tomar decisões que tiveram impactos substantivos sobre as eleições ${ }^{18}$.

A aplicação da lei para impugnar as candidaturas às eleições de 2010 gerou grande impacto sobre o processo eleitoral. Os atingidos provocaram o TSE e o TSF com recursos e ações ${ }^{19}$ arguindo a inconstitucionalidade da lei, pois violava a presunção de inocência, e sua inaplicabilidade às eleições daquele ano. As decisões dos recursos foram bastante contraditórias e demoradas, criando incertezas para candidatos e eleitores até depois da posse dos eleitos. Após votações, manobras e pressões para o tribunal definir o problema, o STF decidiu, no RE n 633703, em 23 de março de 2011, que a Lei da Ficha Limpa só valeria para as eleições de 2012 e os "barrados" em 2010 poderiam assumir. $O$ voto decisivo foi dado pelo ministro Luiz Fux, recémempossado no cargo.

O caso da Ficha Limpa é significativo do engajamento de associações de juristas e magistrados coligadas a outros movimentos sociais, que visou a promoção da moralidade política e encontrou ressonância nos ministros do TSE e do STF. Embora a decisão final tenha sido aceita e considerada correta pelas lideranças políticas, tanto do ponto de vista de fazer prevalecer a anterioridade para a alteração da legislação eleitoral quanto para a criação, pelo Congresso, de regras rigorosas visando promover a moralidade política a partir da iniciativa

\footnotetext{
18 Cinco decisões importantes do TSE: a verticalização das coligações partidárias, a definição do número de vereadores, a inconstitucionalidade da cláusula de barreira, a redefinição do fundo partidário e o estabelecimento da fidelidade partidária. Todas foram objetos de reação políticolegislativa pelo Congresso (CALDEIRA, 2010).

19 Recurso Extraordinário (RE) n 633703; Ação Declaratória de Constitucionalidade (ADC) $n^{\circ} 29$; Ação Declaratória de Constitucionalidade (ADC) n 30; e Ação Direta de Inconstitucionalidade (ADI) $n^{\circ} 4578$.
} 
popular, é significativo que cinco ministros tenham votado em bases principistas, querendo fazer prevalecer o princípio da moralidade sobre o da anualidade, tradicionalmente aplicado no Brasil e um dos pontos fundamentais dos pactos para a eliminação de casuísmos eleitorais desde a Revolução de 1930. Isso indica um engajamento dos ministros em uma política genérica de moralização do Estado, distanciando-se da tradição que fez consolidar a estabilidade das normas e procedimentos eleitorais, garantidas pelo Judiciário como um imperativo da ordem política eleitoralmente competitiva no Brasil.

Assim, abriu-se espaço para a redefinição do papel do Judiciário na competição política e a mobilização passou a visar a promoção de valores substantivos pelas decisões judiciais. Formaram-se, então, novos pontos de tensão na jurisprudência do Tribunal sobre questões críticas nas relações entre governo e oposição. Mais recentemente, o combate à corrupção passou das regras de competição política e da administração pública para incidir sobre prerrogativas parlamentares e atribuições do Congresso.

Outro ponto são os impactos institucionais provocados pela Ação Penal $n^{\circ} 470$. Desde o primeiro semestre de 2012, já foi apresentada uma série de problemas, tais como: a não decisão prévia sobre pontos omissos ou controvertidos dos procedimentos; os embates quanto à fixação de data e agenda para o julgamento; a decisão sobre o não desmembramento do processo, contrariando decisões anteriores do STF sobre a questão; as divergências sobre o impedimento ou não de vários ministros no julgamento; o encaminhamento do chamado "voto fatiado"; e a polêmica adoção da teoria do domínio do fato, que levou à condenação de vários acusados, com base em indícios e testemunhos.

As implicações institucionais desse julgamento podem ser vistas pelos temas do foro privilegiado, da publicidade e da acumulação de atribuições do STF enquanto tribunal de única ou última instância.

A regra segundo a qual os ocupantes de determinados cargos tem direito a foro especial para serem julgados por tribunais superiores faz parte de nossa história. Adotada desde a Constituição de 1824 e preservada pela de 1891, as Constituições posteriores ampliaram os 
ocupantes de cargos beneficiados por ela. Mesmo no regime militar, ampliou-se o seu alcance, com o objetivo de tornar mais expeditas as punições a parlamentares e ocupantes de cargos públicos ${ }^{20}$.

A Constituição de 1988 ampliou os cargos que eram beneficiados pelo foro privilegiado, compreendendo, em 1999, os comandantes militares (art. 102, I, c, com redação dada pela EC $n^{\circ} 23$, de 1999). Quanto às imunidades parlamentares, a Constituição combinou a necessidade de licença da Casa para o início do processo em qualquer crime e o foro privilegiado no STF. Em 2001, a regra foi modificada, para permitir que o STF pudesse iniciar o processo, que seria aprovado (art. 52 , $\S 3^{\circ}$, com redação dada pela $E C n^{\circ} 35$, de 2001).

Tradicionalmente, o foro privilegiado foi justificado como uma proteção para o próprio Estado, para preservar os titulares de responsabilidades públicas contra o uso faccioso da Justiça. A sua extensão aos parlamentares modificava seu significado de uma prerrogativa de classe para o de uma proteção à representação popular. Nas Constituições de 1934 e 1946, o foro privilegiado foi ampliado aos membros dos tribunais federais e aos desembargadores estaduais, além da extensão da imunidade aos parlamentares e seus suplentes, o que foi associado com outras novas atribuições conferidas à Justiça Federal para controlar o uso faccioso dos poderes nos estados e garantir os direitos da oposição política e à contestação civil.

O fortalecimento do foro privilegiado e as imunidades parlamentares na Constituição de 1988 foi nessa mesma lógica: a de proporcionar garantias adicionais à representação política. Como nos períodos anteriores, os processos em foro privilegiado foram criados para desestimular que a acusação e o julgamento penal de responsáveis políticos fossem exercidos, confundindo-se a proteção jurídica e a preservação de prerrogativas de classe.

20 A Súmula 394, do STF, de 1964, estendeu o foro especial para os processos iniciados após a cessação do mandato por crimes durante o exercício funcional. A Emenda Constitucional $n^{\circ} 1$, de 1969, limitou a inviolabilidade dos parlamentares, excluindo dela os crimes contra a segurança nacional e estendendo a eles o foro especial no STF para os crimes comuns (art. $32, \S \S 1^{\circ}$ e $2^{\circ}$ ). 
No entanto, desde a transição democrática, a luta contra a corrupção atinge novos sentidos, condenando sistematicamente os desvios no exercício das funções públicas, do ponto de vista da maior efetividade dos controles e da participação cidadã. O foro especial era associado a privilégio de classe, sendo a "classe política" a beneficiária de imunidades associadas a suas oportunidades diferenciais de acesso aos cargos públicos. Um dos pontos da luta contra a corrupção era o combate ao foro privilegiado.

Com o início do governo Lula, inverteram-se as posições dos principais contendores políticos no governo e na oposição. O escândalo do mensalão deu novos contornos à luta contra a corrupção. O próprio STF foi investido da punição dos acusados. O foro privilegiado deixou de ser um obstáculo e passou a ser um ponto de apoio para os movimentos de combate à corrupção. Na AP $n^{\circ} 470$, contrariando suas decisões anteriores e apesar das divergências jurisprudenciais, o STF assumiu para si o encargo de examinar o caso em sua integridade e julgar todos os acusados. O acolhimento pode ser visto não tanto como uma aliança da maioria dos ministros do STF com a oposição, mas como uma permeabilidade sua a demandas de moralidade e sensibilidade dos movimentos da opinião pública, associada à aceitação de usar uma gama mais ampla de técnicas jurídicas, mesmo em campos mais estritos, como o do Direito e processo penal. Não é que se tornem pragmáticos, mas usam de forma mais aberta argumentos pragmáticos e a adaptação/moldagem de técnicas jurídicas.

Pelo que se verifica até o momento, qualquer que seja o resultado final do processo - que resultou em pesadas condenações dos acusados - o Supremo Tribunal Federal irá enfrentar importantes consequências institucionais. Inicialmente, pelos impactos dos processos penais que lhe serão encaminhados e cuja resposta será crescentemente demandada. Será um bom tema de análise o andamento de outras ações penais no STF (a começar pelo chamado "mensalão mineiro") e a comparação da orientação dos atuais e futuros ministros em relação aos pontos controvertidos do julgamento da AP $n^{\circ} 470$. 
O segundo ponto diz respeito às insuficiências dos próprios procedimentos adotados. Como uma alta corte de justiça de instância única, pode-se dizer que o STF padece de dois problemas contrários: insuficiência e excesso de publicidade. A publicidade é insuficiente, pois não se adotam procedimentos de produção pública de provas, tal como nos júris do common law e tribunais internacionais. A produção e exame público das provas é um procedimento essencial para que as partes e o público possam certificar-se da qualidade e validade das evidências produzidas, e para restringir as possibilidades de seu uso tópico e seletivo pelas partes e julgadores. Essa necessidade é tanto maior quando os julgadores adotam metáforas e argumentos pragmáticos. Porém, há excesso de publicidade quando se considera como foram tomadas as decisões sobre procedimentos para a organização e o andamento das sessões. A publicidade teatralizou as tomadas de posição e o enfrentamento entre ministros, configurando uma arena polarizada antes mesmo da apreciação substantiva do caso. As questões de liderança institucional e de relacionamento entre os ministros vieram a primeiro plano, tornando-se uma arena de enfrentamento de "egos".

Enfim, a concentração de poderes do STF tem implicações relevantes, pois é difícil que se aceite a imparcialidade e objetividade de um tribunal que é, ao mesmo tempo, Corte Constitucional, copartícipe da produção normativa do Estado e Tribunal Penal, que julga não só os processos de responsabilidade, mas todos os casos penais que envolvem os demais responsáveis políticos. Se os papéis de Corte Constitucional e Tribunal de Justiça Penal podem ser compatíveis quando são reservados a casos de responsabilidade penal do chefe de Estado e, eventualmente, outros poucos altos dirigentes do país, eles tendem a ser conflituosos quando a responsabilização penal se torna mais frequente e atinge um conjunto maior de dirigentes políticos ${ }^{21}$. Isso

21 Em vários países, a Corte Constitucional tem algumas funções de Alta Corte de Justiça, enquanto são os tribunais comuns que exercem o papel de justiça penal dos dirigentes políticos. Foram consultadas as constituições de países europeus e só o Tribunal Constitucional austríaco tem poderes de controle da constitucionalidade, de julgamento de responsabilidade política e de tribunal penal. 
porque os julgamentos do tribunal incidem sobre a própria composição do Legislativo 22 .

\section{Conclusão}

As lideranças políticas não ficarão inertes diante dos problemas apresentados pelo julgamento da AP $n^{\circ} 470$. Por isso, ocorrerão desdobramentos, como a proposição de Projeto de Lei para regular esse tipo de processo no Superior Tribunal Federal, a definição mais clara das prerrogativas e deveres dos ministros em relação à mídia e aos demais poderes do Estado, e a definição de regras nos processos de responsabilidade dos ministros do STF.

As relações entre ministros do STF, parlamentares e a presidência da República tenderão a continuar tensionadas. Em um cenário positivo, a decisão do Superior Tribunal Federal terá fortes repercussões positivas junto à população, o que incentivará as lideranças políticas a promoverem no Congresso reformas legislativas referentes a fundos públicos para o financiamento de partidos e campanhas políticas, assim como o fortalecimento do controle do uso dos recursos públicos. Essa dinâmica virtuosa significaria um processo de mudança dos costumes políticos no país. Seria a efetivação do programa reformista das práticas políticas que é propugnado por juízes, juristas, movimentos cívicos e lideranças políticas.

Porém, parece que essa dinâmica virtuosa não é a mais provável. Primeiro, porque ela não "fecha bem" com as práticas e os interesses políticos dos demais agentes do sistema político. No nosso sistema multipartidário e de eleições proporcionais, as alianças do chamado presidencialismo de coalizão envolvem trocas de apoio por participação no governo, com implicações implícitas de autonomia para tomar as

\footnotetext{
22 Esse problema estava implícito, mas foi pouco tematizado no debate sobre se a condenação penal de parlamentares implicaria a perda automática dos seus mandatos ou se depende de decisão da Casa respectiva do Congresso.
} 
decisões relativas a cada pasta ou órgão público. Essa autonomia está vinculada às relações entre interesses públicos e privados na política brasileira, em que o acesso privilegiado ao Estado representa uma parte relevante das oportunidades de investimento e lucro para o empresariado. Em outros termos, é pouco provável que a atuação do Judiciário para reformas cívicas das práticas políticas tenham impactos mais profundos sobre a cultura política. O mais provável é que haja reações políticas para que o Congresso limite o protagonismo dos tribunais nesse campo.

Em um cenário conflituoso, o STF torna-se uma arena adicional na qual se desenrolam as lutas político-partidárias. Daí pode resultar o sobreinvestimento de seu papel de Corte de Justiça para se promover a responsabilidade de dirigentes políticos em escândalos mais ou menos amplos. As lideranças políticas passariam a escolher ministros com vínculos político-partidários mais fortes, para que tenham atuação mais combativa e afinada com seus objetivos políticos. Consequentemente, esses ministros enfrentariam fortes resistências dos oponentes políticos, materializadas em tentativas de desqualificação e acirramento das arguições dos novos nomeados no Senado. O processo de seleção tornar-se-ia mais próximo do que ocorre nos Estados Unidos, de caráter majoritário, para posições num tribunal que tem papéis consensualistas.

Pode-se imaginar as consequências de vários ministros com características de partidarismo que fiquem por volta de 30 anos no tribunal. Ou, inversamente, o STF pode ser objeto de desinvestimento, com a aliança das forças partidárias, para realizar reformas que visem limitar seus poderes, criando normas que impeçam sua atuação mais efetiva. Se o Superior Tribunal Federal declarar a inconstitucionalidade dessas normas, exercendo seu papel de tribunal constitucional, será posto como enfrentamento ao Legislativo, defesa corporativa de seus superpoderes ou tutela sobre a vontade da maioria. Em outros termos, tal como aconteceu com as CPIs, as forças partidárias atuarão para neutralizar os instrumentos de decisão judicial, seja por reformas legislativas ou constitucionais ou por ações estratégicas face ao tribunal. 
A dinâmica mais recente tem acentuado os conflitos entre juízes e governo. Mas o novo papel assumido pelo STF também entra em divergência com a oposição e suas bases conservadoras, que tenderão a resistir a esse novo padrão de atuação. O mais provável é que, dadas as formas consensuais e práticas privatistas da política brasileira, haja o encaminhamento para uma acomodação entre lideranças políticas e elites judiciais, a fim de limitar o alcance do impacto da mobilização da moralidade política nos tribunais, reafirmando o papel do Poder Judiciário como organizador das condições formais para a competição política e garantia contra as violações de direitos individuais e coletivos, em que jurisdição constitucional concentrada é exercida de modo compatível com a lógica dos freios e contrapesos.

\section{Referências}

CALDEIRA, César. Regras da disputa eleitoral: quem decide o quê, quando e como. Revista EMARF, Rio de janeiro, v. 14, n. 1, p. 71-106, nov. 2010.

CARVALHO, E. Revisão abstrata da legislação e judicialização da política no Brasil. 2005. Tese (Doutorado em Ciência Política) Faculdade de Filosofia, Letras e Ciências Humanas, Universidade de São Paulo, São Paulo. 2005.

CONSELHO NACIONAL DE JUSTIÇA. Metas nacionais de nivelamento: 2009. Disponível em: <http://www.cnj.jus.br/images/ stories/docs_cnj/resolucao/rescnj_70_ii.pdf>. Acesso em: 18 fev. 2010.

COSTA, A. et al. A quem interessa o controle concentrado de constiucionalidade? Um perfil das decisões de procedência em ADIs. In: ENCONTRO DA ASSOCIAÇÃO BRASILEIRA DE CIÊNCIA POLÍTICA, 7.,. Recife, 2010. Anais... Recife: ABCP, 2010. Disponível em: <http:// www.cienciapolitica.org.br/7o-encontro-da-abcp/\#.UswaHPRDvMU>. Acesso em: 15 fev. 2011.

IÓRIO FILHO, R. M.; DUARTE, F. O Supremo Tribunal Federal e a Lei da Ficha Limpa: uma questão de déficit democrático. In: ENCONTRO,DA 
ASSOCIAÇÃO BRASILEIRA DE CIÊNCIA POLÍTICA, 8., Porto Alegre, 2012. Anais... Gramado: ABCP, 2012. Disponível em: <http://www. cienciapolitica.org.br/encontros/8o-encontro-abcp/>. Acesso em: 15 fev. 2011.

KOERNER, Andrei. Ativismo judicial? Jurisprudência constitucional e política no STF pós-88. Novos Estudos - CEBRAP, São Paulo, n. 96, jul. 2013. Disponível em: <http://www.scielo.br/scielo.php?script=sci arttext\&pid=S0101-33002013000200006\&Ing=en\&nrm=iso>. Acesso em: $1^{\circ}$ nov. 2013.

KOERNER, Andrei; FREITAS, Lígia Barros de. O Supremo na Constituinte e a Constituinte no Supremo. Disponível em <http:// www.redalyc.org/articulo.oa? $i d=67326438009>$. Acesso em: $1^{\circ}$ nov. 2013.

PACHECO, C. O Supremo Tribunal Federal e a Reforma do Estado: uma análise das Ações de Inconstitucionalidade julgadas no primeiro mandato de Fernando Henrique Cardoso. 2006. 416 f. Tese (Doutorado em Ciência Política) - Universidade Estadual de Campinas, Campinas, 2006.

POGREBINSCHI, Thamy. Judicialização ou representação? Política, direito e democracia no Brasil. Rio de Janeiro: Elsevier, 2011.

SUNFELD, C. et al. Controle de constitucionalidade e judicialização: O STF frente à sociedade e aos poderes. Belo Horizonte: Faculdade de Filosofia e Ciências Humanas, 2010.

VIANNA, Luis Werneck et al. A judicialização da política e das relações sociais no Brasil. Rio de Janeiro: Renavan, 1999.

Recebido em: 08/11/13

Aprovado em: 05/12/13 